\title{
sobre: Esto fui (memorias de la infancia), de Juan Filloy, con Apostillas de Candelaria de Olmos, Ríc cuarto: Unirío Editora, 2019.
}

\author{
PABLO DEMA Universidad Nacional de Río Cuarto, Argentina / pablodema@yahoo.com.ar
}

Esto fui (memorias de la infancia) es el octavo título de la Colección Filloy de UniRío Editora (de la Universidad Nacional de Río Cuarto) dirigida por Candelaria de Olmos. Lo precedieron Urumpa (2014), Sagesse (2015), Caterva, Usaland, Balumba (los tres de 2016), Ignitus (2017) y L'ambigú (2018). Se trata de la reedición del libro publicado en 1994 en Córdoba por Marcos Lerner Editora. La presente edición cuenta con algunos fragmentos inéditos y con una treintena de imágenes adicionales que ilustran la galería de personajes, lugares y situaciones narradas por Filloy a lo largo del libro; son fotos familiares y del barrio Pueblo General Paz de la ciudad de Córdoba donde el autor se crió, dibujos, cartas y documentos personales. Además, el libro cuenta con dos importantes paratextos a cargo de Candelaria de Olmos, los cuales por su extensión y profundidad justificarían su publicación como obra independiente. En efecto, la directora de la colección, por un lado, introduce la obra de Filloy con un estudio que encuadra teóricamente el libro en el género memorias y lo sitúa en la tradición latinoamericana y argentina, comparándolo con textos canónicos como Recuerdos de provincia de Domingo Faustino Sarmiento. Por otra parte, de Olmos incorpora una serie de «apostillas» que, página por página, van complementando los distintos aspectos de las memorias de Filloy, tanto los recuerdos que el autor va «pialando» como los olvidos que sigue «hurgando» desde el extremo de su extensa vida.

Según se desprende del estudio preliminar — apoyado en los aportes teóricos de Walter Benjamin, Sylvia Molloy, José Amícola y Leonor Arfuch, entre otros—, las memorias, a diferencia de las autobiografías, se caracterizan por su carácter misceláneo y fragmentario. Este rasgo genérico no solo se verifica en Esto fui sino que es asumido por el propio Filloy con deleite desde los primeros párrafos del «Prefacio». «Mi manera de ser fiel — dice — es contar, no reflexionar lo que cuento. Rapsoda de emociones impúberes, [se aboca] a pescar, cuando pican, las sonrisas del pasado», los recuerdos de la infancia que «cruza pimpante las rémoras y atavismos que acumulan las etapas de la edad». Es decir que no se trata más que de permitir que afloren en la memoria del «hombre provecto» las imágenes «preimpresas» en la memoria en aquel tiempo en el que la candidez y la inocencia dominaron los días.

Para citar este artículo: Dema, P. (2019). Sobre: Esto fui (memorias de la infancia), de Juan Filloy, con Apostillas de Candelaria de Olmos. El taco en la brea, 10 (junio-noviembre), 212-214. Santa Fe, Argentina: UNL. DOI: $10.14409 /$ tb.v1i10.8700 
Pero pese a que no es un libro sistemático, los recuerdos se arraciman en series presentadas bajo subtítulos. «Los míos», por ejemplo, es la presentación de los miembros de su familia ubicados en un orden que se relaciona quizás con su cercanía afectiva. Así, dedica un apartado especial para «mamá», «papá», «Manuel» (el primogénito), «Benito» (el segundo hermano), «Pablo» Cremer (medio hermano de Juan por parte de madre) y el «tío Pepe». En este punto son de gran utilidad las apostillas que reponen el derrotero completo de la madre de Filloy (casada con el padre de este en segundas nupcias), la existencia de los medio hermanos y la relación compleja con la hermana Rosa, quien está desdibujada en las memorias. Poco después de «Los míos» aparece una sección subtitulada «Ámbito familiar», donde se vuelve sobre el mismo tema pero poniendo el énfasis en la dinámica cotidiana. En todos estos pasajes cobra gran importancia el origen humilde de los padres inmigrantes (gallego don Benito Filloy, francesa la madre) y el despliegue de una cultura del trabajo ejercida en el negocio familiar: un almacén de comestibles, despacho de bebidas y tienda de productos de todo tipo. Ese espacio hogareño y comercial es punto de referencia de todos los personajes del barrio Pueblo General Paz del cual se cuenta su origen y desarrollo en importantes apartados como «Afinquémonos» $\mathrm{y}$ «Hábitat». En ese sentido, ningún aspecto parece haber escapado a las impresiones del niño Filloy. En sus memorias habla tanto de urbanismo, hábitos de higiene y arquitectura como de los oficios y el desarrollo económico, de la fundación de las empresas culturales de las que participa (por ejemplo la Biblioteca Popular Vélez Sársfield) como de las aventuras en el río Suquía, los juegos infantiles y la escolaridad. En las «Viñetas», las «Semblanzas» y los «Micro episodios» se despliega un abanico de perlas humorísticas y tiernas, de curiosidades e información que, en conjunto, además de deleitar, configuran un abigarrado cuadro histórico, revelan un sustrato de experiencias que esclarecen la poética del autor y brindan claves de su obra literaria. En este punto, las apostillas son imprescindibles porque en ellas Candelaria de Olmos establece relaciones que difícilmente un lector que no conozca en profundidad la obra de Filloy podría trazar para sacar conclusiones generales. En algunos casos, se trata de mostrar que un episodio ocurrido en el «boliche» de los Filloy está recreado con variantes en algún libro o que un rasgo del carácter del autor o una afición (la grafología, por ejemplo) se le atribuye luego a un personaje. Pero en otras apostillas de Olmos, a partir del mundo histórico, cultural y familiar de Filloy, traza un perfil que lo define en oposición a figuras fundamentales del campo literario argentino. La investigadora nos hace notar, por ejemplo, que «si Borges tiene adentro de su casa una biblioteca y afuera el suburbio; Filloy, en cambio, tiene su casa invadida por el suburbio y la biblioteca, afuera». Y mientras que Borges se cría en un jardín tras una verja con lanzas, Filloy lo hace en un «turbio almacén», lo cual tiene consecuencias importantes en la definición de ambas poéticas. Entre el «yo creí» de Borges, en relación con su imaginario sobre las experiencias de la vida marginal y sus personajes — nos dice de Olmos — y el «yo evoco» de Filloy hay una distancia que es literaria pero también de clase. Estas síntesis se desprenden luego de un largo y paciente trabajo de lectura de la obra de Filloy y de la reposición de datos históricos que de Olmos laboriosamente recobra de distintos documentos del Archivo Histórico Municipal de Río Cuarto, del archivo del Colegio Monserrat (donde Filloy hizo el secundario), del Archivo Histórico de la UNC y el de la Biblioteca Popular Vélez Sarsfield, más otros archivos familiares y la bibliografía crítica existente.

Esta edición mantiene algunos pasajes redundantes o repetidos que vienen de la edición de 1994 los cuales se podrían atribuir tanto a lo avanzado de la edad del autor al momento de escribir las memorias (cien años cumplidos) como a un modo de trabajo ya que la reubicación de textos 
propios en distintos contextos (ficcionales o no ficcionales) es una marca estilística de Filloy. Otra marca de estilo es, por supuesto, el despliegue de una prosa deslumbrante y lujosa (de Olmos insiste mucho en la impronta modernista en ese sentido) conjuntamente con el conocido desenfado de Filloy a la hora de referirse con crudeza a cuestiones fisiológicas y escatológicas cuando narra anécdotas humorísticas. Además, en este libro en particular son deliciosas las etimologías de términos populares gestados muchas veces al calor de errores surgidos de la interacción entre inmigrantes de distintas nacionalidades en el barrio. En Esto fui vemos aparecer términos como «ñaupa», «chanfle», «pebete» (derivado de la sigla de una revista para chicos, PBT) y «chinchibira», este último surgido de una forma oral del término anglosajón ginger-beer, correspondiente a una bebida fabricada por Mr. Cunnington en el barrio Gral. Paz. Por último, y esta también es marca de estilo de Filloy, los pasajes narrativos y descriptivos están enmarcados por reflexiones generales sobre temas diversos, en especial el paso del tiempo y las etapas de la vida. Hacia el final del libro se acentúa este rasgo hasta constituirse en algunos pasajes en una serie de grajeas aforísticas como por ejemplo una que dice: «La infancia es risa, por eso el niño expande. La juventud es sonrisa, por eso conquista. La adultez es sorna, por eso se retrae. La vejez es sarcasmo, por eso se acurruca». Con respecto al tema del paso del tiempo y los cambios culturales, la visión de Filloy se vuelve nostálgica y con visos de protesta, adquiriendo la forma de sus famosas «diatribas». Como en muchos de sus libros, deplora la cultura del consumo, la debilidad de carácter de los padres modernos y la sobreprotección a los niños, recordándonos que su infancia fue feliz en un tiempo en el que los padres no prodigaban ni mimos ni juguetes ni festejaban los cumpleaños.

Leído al hilo de los demás títulos de la colección y puesto, obviamente, en relación con el resto de la obra y la creciente bibliografía crítica (recordemos también la publicación de Un atleta de la letras. Biografía literaria de Juan Filloy escrita recientemente por Ariel Magnus y citada por Candelaria de Olmos en las apostillas), Esto fui es una importante pieza para consolidar el corpus filloyiano. El autor de Op Oloop es, según sus editores, un long seller; alguien que vende poco pero que no deja de conquistar, uno a uno, a sus lectores sin prisa pero sin pausa, lo cual redunda en un lento proceso de consolidación de la figura de un escritor que a esta altura resulta insoslayable a la hora de dar cuenta del mapa de las letras argentinas. Una prueba muy reciente de ello son estas palabras de Jorge Bracamonte tomadas de su trabajo «Área cultural y transformaciones artísticas: la narrativa contemporánea de Córdoba, Santa Fe y entre Ríos» incorporado en Una literatura en aflicción, el volumen 12 de la Historia crítica de la literatura argentina: «Después de la intensa marca de Leopoldo Lugones, la gran figura contemporánea que se destaca en el siglo XX es Juan Filloy». Esto fui (memorias de la infancia) es una excelente oportunidad para adentrarse en la obra de un escritor mayor a través de los ojos del niño que fue. 